\title{
Adaptation of Physics Metacognition Inventory to Turkish
}

\section{Zeynep Koyunlu Ünlü (iD) 1,* İlbilge Dökme (iD)2}

\author{
${ }^{1}$ Yozgat Bozok University, Faculty of Education, Department of Primary Education, Yozgat, Turkey \\ ${ }^{2}$ Gazi University, Faculty of Gazi Education, Department of Mathematics and Science Education, Ankara, \\ Turkey
}

\section{ARTICLE HISTORY}

Received: 23 November 2018

Revised: 23 February 2019

Accepted: 05 March 2019

\section{KEYWORDS}

Physics education, Metacognition, Scale adaptation

\begin{abstract}
This study aimed to adapt the Physical Metacognition Inventory (PMI) developed by Taasoobshirazi and Farley (2013) to Turkish. PMI consists of 24 items and six factors. The scale items were translated into Turkish by the researchers, and a Turkish-English comprehensibility form was prepared to elicit the opinions of Turkish-English language experts. After making the necessary revision according to the feedback of the experts, a confirmatory factor analysis (CFA) was undertaken. A total of 554 students participated in the research, selected from prospective teachers enrolled in the science teaching and classroom teaching programs offered by education faculties or prospective engineers studying in engineering faculties. The results of CFA revealed that the factors and related items of the adapted scale were the same as in the original version. The reliability of measurement was calculated as 0.93 for the whole scale. The adapted PMI presented in this research can be applied to evaluate the level of metacognition used by high school and university students in solving physics problems.
\end{abstract}

\section{INTRODUCTION}

Metacognition refers to knowledge and cognition about a cognitive phenomenon (Flavell, 1979). Thinking about metacognition is to become aware of what we know and what we do not know (Blakey \& Spence, 1990; Lai, 2011). In other words, it means reflecting, understanding and managing one's learning (Schraw \& Dennison, 1994). When the definitions related to metacognition are examined, it is observed that they generally focus on the individual's awareness and control of his/her knowledge and processes related to learning while cognition is more related to the mental learning of individuals.

Metacognition consists of two dimensions: knowledge of cognition related to one's own cognitive resources and regulation of cognition containing information used in the problemsolving process. Knowledge of cognition comprises the sub-scales of declarative, procedural and conditional knowledge, and regulation of cognition encompasses planning, monitoring,

CONTACT: Zeynep Koyunlu Ünlü $\bigotimes$ zeynepko.unlu@gmail.com $\equiv$ Yozgat Bozok University, Faculty of Education, Division of Classroom Instruction Education, Yozgat, Turkey 
evaluation, debugging, and information management (Taasoobshirazi \& Farley, 2013). The subdimensions of the metacognition are presented in Figure 1.

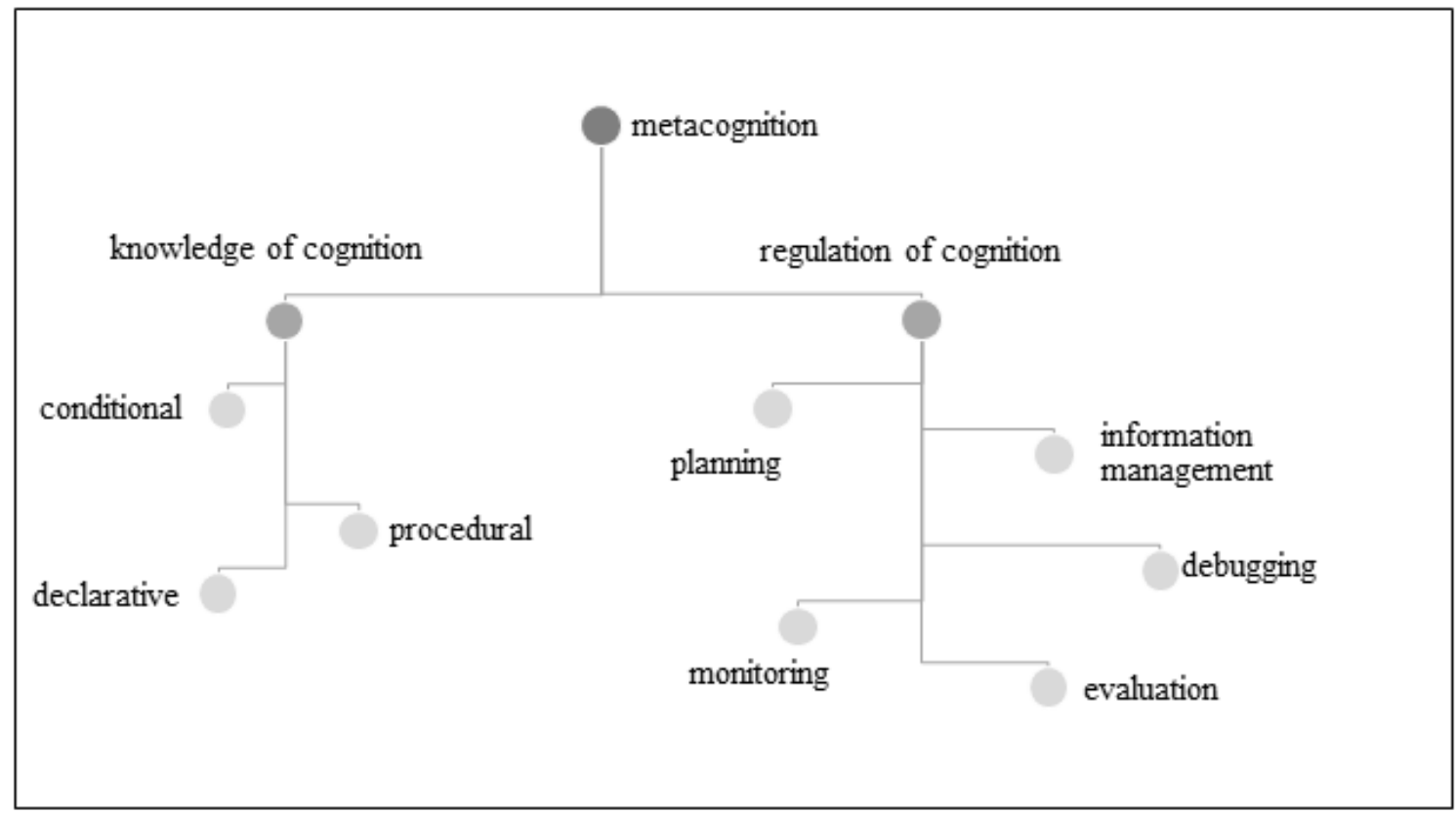

Figure 1. Sub-scales of metacognition (Taasoobshirazi \& Farley, 2013)

The knowledge of cognition as the first component of metacognition during problem solving tasks refers to the effect of the students' performance in relation to how they use these strategies appropriately in accordance with the task (Brown, 1978). Declarative knowledge, a sub-scale of knowledge of cognition, is related to the factors affecting the person himself/herself and his/her learning performance. Procedural knowledge concerns knowing what strategy to use and when. Conditional knowledge is knowing when and why to use the remaining components of knowledge of cognition (Taasoobshirazi \& Farley, 2013). The regulation of cognition as the second component of metacognition also refers to how learners monitor, control, and regulate their cognition and learning (Pintrich, 2002; Schraw, Crippen \& Hartley, 2006; Schraw \& Moshman, 1995). Of the sub-scales of regulation of cognition, planning concerns goal setting, activation of past information, and arranging time; monitoring is the self-evaluation of an individual at certain intervals; evaluation refers to reviewing one's learning and associated products and process; debugging is the elimination of unnecessary information; and lastly information management concerns using individual-specific strategies to solve a problem effectively (Taasoobshirazi \& Farley, 2013).

Over the past decades, metacognition received much attention in the science education literature. Particularly in recent years, metacognitive instruction has been shown to improve students' conceptual understanding of science (Abd-El-Khalick \& Akerson 2009; Colthorpe, Sharifirad, Ainscough, Anderson \& Zimbardi, 2018) and develop their higher-order thinking (Ghanizadeh, 2018) and problem-solving skills (Akben, 2018). Also, metacognition has been considered as one of the most important issues in the students' success in problem-solving. For example, in physics classes, students should practice meta-cognitively throughout processes of solving physics problems by defining the goals in the problem, mental representation of the problem, selecting the proper strategies, connecting prior knowledge, planning, monitoring, and evaluation of possible solutions (Güss \& Wiley, 2007; Taasoobshirazi \& Farley, 2013; Taasoobshirazi, Bailey \& Farley, 2015).

Research has revealed that some students are unable to solve non-routine physics problems 
because of the lack of the metacognitive skills or awareness (Selçuk, Çalıskan \& Erol 2007; Anzai \& Yokoyama 1984; Stewart \& Rudolph 2001). Students can acquire metacognitive knowledge theoretically, but there is a strong need for practical implementation during problem-solving processes in physics lessons (Georghiades, 2004; Thomas, 2012; Zohara \& Barzilai, 2013; Hutner \& Markman, 2016). Metacognitive tasks in physics courses allow the students to gain experience and develop metacognitive skills (Veenman \& Spaans 2005; Veenman, 2011).

The first attempt to include metacognitive thinking in the physics problem-solving process seems to be to reveal the metacognitive awareness of students. Because it is important to determine what level the students have before developing their metacognition (Öztürk, 2017). At this point, one more important element is the development or adaptation of standardized instruments for the participants. Therefore, the first aim of this study is to adapt into Turkish the Physics Metacognition Inventory (PMI) developed by Taasoobshirazi and Farley, (2013), which is a 5-point, Likert-type scale. However, first it is necessary to determine the cognitive status of students prior to commencing the research. One potential reason for the lack of studies examining the role of metacognition on physics problem-solving is the absence of an inventory that measures metacognition for science problem-solving. Most of the existing research examining metacognition for problem-solving in science has done so using primarily verbal interviews or a small set of researcher-developed items (Rozencwajg, 2003), and this indicates that students who are more metacognitive during physics problem-solving are more likely to correctly solve the problems (Neto \& Valente, 1997; Rozencwajg, 2003). The lack of research on the role of metacognition in physics problem-solving is problematic given the significance of problem-solving for success and improvement in physics (Chi, 2006). A review of the literature revealed the availability of attitude scales related to physics teaching and physics laboratories (Kurnaz \& Yiğit, 2010; Nuhoğlu \& Yalçın, 2004; Tekbıyık \& Akdeniz, 2010); however, there is no measurement tool in the Turkish literature for measuring physics metacognition. In the current study, PMI developed by Taasoobshirazi and Farley (2013) was adapted to Turkish to fill the gap in the national literature and guide researchers and practitioners.

\section{METHOD}

This was a scale adaptation study. Scale adaptation refers to the process in which a scale that was developed in another language and proven to be reliable and valid is adapted to another language and culture and made ready for use through reliability and validity tests (Seçer, 2015). In this research, PMI developed by Taasoobshirazi and Farley (2013) was adapted to Turkish.

\subsection{Study Group}

The study group was selected according to the criterion sampling technique, in which observation units may be persons, objects or situations with specific characteristics (Patton, 2002). The criterion in this study was determined as the participants in this research group taking the physics course at the university level.

The study group consisted of prospective teachers enrolled in the science teaching and classroom teaching programs and prospective engineers studying in the faculty of technology in two universities located in the Central Anatolia Region of Turkey. Table 1 presents detailed information about the main study group.

A total of 96 students (62 female, 34 male) participated in the pilot study and 458 students (347 female, 111 male) in the main study. In addition, one Turkish language expert, one English language expert, and six field experts with a $\mathrm{PhD}$ in science and physics education 
were consulted during the scale adaptation process. Analyzes were carried out from the data of 458 students who participated in main study. The pilot study focused on whether there were any problems understanding of PMI.

Table 1. Frequency and percentages of the participant prospective teachers according to gender and department

\begin{tabular}{llcc}
\hline Variable & Sub-variable & Frequency & Percentage \\
\hline \multirow{2}{*}{ Gender } & Female & 347 & 78 \\
& Male & 111 & 22 \\
\hline \multirow{3}{*}{ Department } & Science Teaching & 223 & 49 \\
& Classroom Teaching & 184 & 40 \\
& Engineering & 51 & 11 \\
\hline
\end{tabular}

\subsection{PMI}

The PMI instrument developed by Taasoobshirazi and Farley (2013) is based on the theory of processing information. It consists of 24 items presented under the two main dimensions of knowledge of cognition and regulation of knowledge, which have a total of six sub-scales: declarative, procedural and conditional (sub-scales of the former), and planning, monitoring, evaluation, debugging, and information management (sub-scales of the latter). Table 2 presents the items under the PMI factors.

Table 2. Items included in the original PMI

\begin{tabular}{|c|c|}
\hline Factors & Items \\
\hline Knowledge of cognition: declarative, procedural, conditional & $5,6,7,11,12,13$ \\
\hline Regulation of knowledge: information management & $4,10,18,23$ \\
\hline monitoring & $2,15,16,21$ \\
\hline evaluation & $8,9,17$ \\
\hline debugging & 3,22 \\
\hline planning & $1,14,19,20,24$ \\
\hline
\end{tabular}

The number of items under the factors of PMI varies between two and six (Table 2). None of the items contain a negative statement. This inventory is based on a 5-point Likert-type scale with the following possible responses: always true of myself (5), almost always true of myself (4), sometimes true of myself (3), rarely true of myself (2), and never true of myself (1) (Taasoobshirazi \& Farley, 2013).

\subsection{Procedure}

As a matter of academic courtesy, the corresponding author of the PMI study (Gita Taasoobshirazi) was contacted and permission was obtained to adapt the scale into Turkish. The scale was first translated into Turkish by the researchers. At this stage, one Turkish and one English language expert were consulted. In the first stage, the translated version of the inventory was completed by five prospective teachers to confirm that the items were understandable. Then, a Turkish-English comprehensibility form was prepared to elicit the opinion of six field experts from science and physics teaching. The correlation coefficients of each expert's score was calculated and the necessary corrections were undertaken by the researchers. After revision according to the feedback from the experts, the Turkish version of the scale was administered to 96 students in a pilot study. The analysis of data obtained from the pilot study revealed that the factors and item distribution were in line with the original scale. Thus, the main study was undertaken with 458 participants and data analysis was conducted. 


\subsection{Data Analysis}

AMOS 21 and SPSS 21 programs were used for data analysis. A confirmatory factor analysis (CFA) was performed using the AMOS 21 program. In CFA, a previously determined model or hypothesis on the relationship between variables is tested (Büyüköztürk, 2004). In this study, the first level multi-factor model for the adapted PMI was tested. The variables that can be observed in this model are grouped under more than one independent dimension (Meydan \& Şeşen, 2015). Using the SPSS 21 program, Cronbach's alpha values were calculated for the whole PMI and each factor to determine reliability of measurement, the corrected item-total correlations of the factors and t-test between the upper and lower $27 \%$ scores were performed, the mean and standard deviation values and the correlations between the sub-scales were determined, and the test-retest reliability was undertaken. In addition, for criterion validity PMI scores were analyzed according to the participants' gender and department.

\section{RESULTS}

\subsection{Translation of PMI into Turkish}

After the translation of PMI into Turkish by the authors, one Turkish and one English language expert were consulted. The Turkish-English comprehensibility form was completed by six science and physics teachers. The experts scored the translation of each item from 1 to 5. The correlation coefficient between the scores of the experts and the mean item scores were calculated. In this process, it was checked whether the mean score given to the translation of the items in the scale was 4.0 or above, and the standard deviation was 0.7 or below. The mean score was calculated as 4.3 and the standard deviation as 0.4. Language experts have suggested some words to be changed. In addition, the recommendations made by the experts do not contain a substance that does not comply with the Turkish culture. This is due to the lack of direct translation.

\subsection{Results of Reliability Analysis}

The measurement reliability values of the Turkish version of the whole PMI and its factors were calculated using the SPSS 21 program. Table 3 shows the measurement reliability values of the sub-scales of both the original and adapted versions of PMI.

Table 3. The measurement reliability values of the sub-scales included in the English and Turkish versions of PMI

\begin{tabular}{lcc}
\hline Sub-scales & English version & Turkish version \\
\hline Factor 1 & 0.90 & 0.87 \\
Factor 2 & 0.91 & 0.86 \\
Factor 3 & 0.87 & 0.8 \\
Factor 4 & 0.78 & 0.8 \\
Factor 5 & 0.92 & 0.72 \\
Factor 6 & 0.68 & 0.74 \\
\hline
\end{tabular}

The measurement reliability of the sub-scales in the English and Turkish PMI ranged from 0.92 to 0.68 , and 0.87 to 0.72 , respectively. This suggests that the measurement reliability of the PMI sub-scales of the adapted scale was at an acceptable level (Nunally, 1978). The overall measurement reliability of the Turkish PMI was calculated as .93.

\subsection{Results of CFA}

The original six-factor structure of PMI was tested via CFA using the AMOS 21 program. Fit indices, namely chi-square goodness $\left(\chi^{2}\right)$, goodness-of-fit index (GFI), adjusted GFI (AGFI), and the root mean square error of approximation (RMSEA) were examined. A scale is 
considered to be acceptable if the values for these indices are as follows: less than 5 for the ratio of $\chi^{2}$ to the degree of freedom, greater than .90 for GFI, greater than .80 for AGFI, greater than .90 for CFI, and .05 to 0.8 for RMSEA (Klein, 1998). All the fit indices obtained were within acceptable psychometric ranges $\left(\chi^{2} / \mathrm{df}=3.55, \mathrm{GFI}=0.86, \mathrm{AGFI}=0.82, \mathrm{CFI}=0.89\right.$, RMSEA=0.07). The tested model is shown in Figure 2.

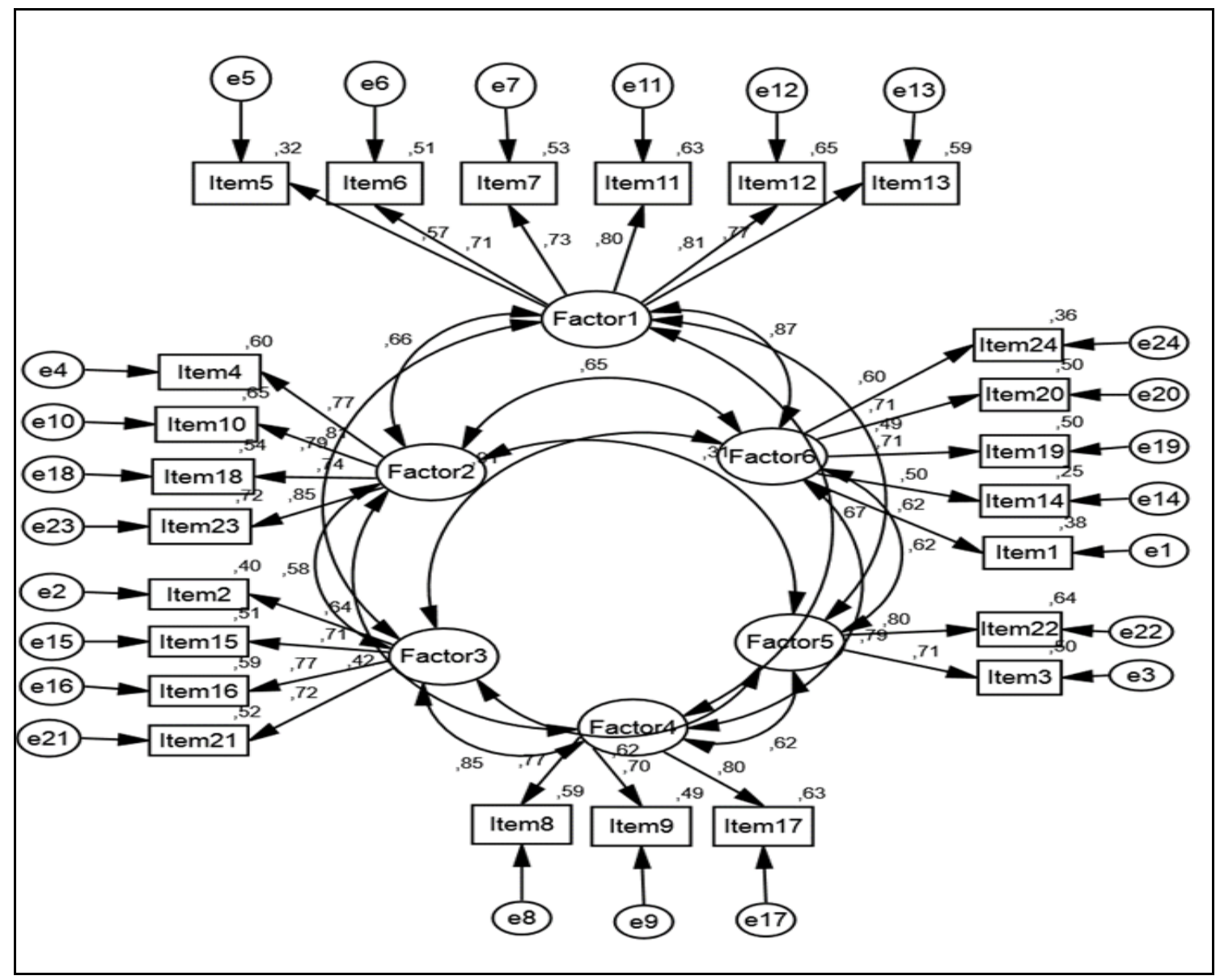

Figure1. The results of CFA of the tested model, $\mathrm{N}=458, \chi^{2} / \mathrm{df}=3.55, \mathrm{p}<0.001$

The factor load values of the items in the scale varied between 0.49 and 0.84 (Figure 2). The ranges of the load values were $0.56-0.8$ for Factor 1, 0.73-0.84 for Factor 2, 0.63-0.76 for Factor 3, 0.7-0.79 for Factor 4, 0.7-0.8 for Factor 5, and 0.49-0.76 for Factor 6. According to these results, all values were statistically significant $(p<0.001)$.

\subsection{Results of PMI Item Analysis}

In order to determine the discriminatory levels of the items in the adapted PMI and their predictive power for the total score, the corrected item-total correlation was calculated using Pearson's product moment correlation, and upper and lower $27 \%$ group comparisons were undertaken employing an independent samples t-test. Table 4 presents the results of the t-test conducted to determine the significance of the differences between the item mean scores of the upper $27 \%$ and lower $27 \%$ groups created according to the PMI total scores.

The corrected item-total correlations ranged from 0.45 to 0.71 , and the $\mathrm{t}$ values were significant $(p<.05)$ (Table 4). Item-total correlation coefficients of $r \geq .40$ are classified as very good (Nunnally \& Bernstein, 1994). In this context, for the adapted inventory, the correlation between the items and the total scale was very good ( $r \geq .40)$. The significance of the $t$ values for the differences between the lower and upper groups was considered to be evidence for the 
discriminative power of the items (Erkuş, 2012; Tezbaşaran, 1996). According to these criteria, it can be stated that all the items in the scale were discriminative.

Table 4. The corrected item-total correlations of PMI factors and the t-test results of the comparison between the upper $27 \%$ and lower $27 \%$ groups

\begin{tabular}{lccc}
\hline Factors & Item No & Corrected Item-Total Correlation & $\mathrm{t}$ \\
\hline & 5 & 0.6 & $12.75^{*}$ \\
Factor 1: Knowledge of cognition: & 6 & 0.66 & $14.12^{*}$ \\
declarative, procedural, & 7 & 0.69 & $14.71^{*}$ \\
conditional & 11 & 0.69 & $16.1^{*}$ \\
& 12 & 0.71 & $17.05^{*}$ \\
& 13 & 0.68 & $16.43^{*}$ \\
\hline & 4 & 0.55 & $11.87^{*}$ \\
Factor 2: Regulation of cognition: & 10 & 0.57 & $12.02^{*}$ \\
information management & 18 & 0.6 & $14.15^{*}$ \\
& 23 & 0.66 & $15.02^{*}$ \\
\hline & 2 & 0.62 & $12.04^{*}$ \\
Factor 3: Regulation of cognition: & 15 & 0.65 & $13.8^{*}$ \\
monitoring & 16 & 0.69 & $15.82^{*}$ \\
& 21 & 0.66 & $14.77^{*}$ \\
\hline Factor 4: Regulation of cognition: & 8 & 0.63 & $14.52^{*}$ \\
evaluation & 9 & 0.53 & $11.84^{*}$ \\
& 17 & 0.67 & $15.4^{*}$ \\
\hline Factor 5: Regulation of cognition: & 3 & 0.45 & $8.77^{*}$ \\
debugging & 22 & 0.52 & $10.65^{*}$ \\
\hline & 1 & 0.61 & $11.13^{*}$ \\
Factor 6: Regulation of cognition: & 14 & 0.52 & $11.13^{*}$ \\
planning & 19 & 0.67 & $13.8^{*}$ \\
& 20 & 0.67 & $14.46^{*}$ \\
& 24 & 0.58 & $11.89^{*}$ \\
\hline
\end{tabular}

\subsection{Correlation between the Sub-Scales of PMI}

Correlation values between the sub-scales of PMI can be seen in Table 5. The correlation values between the sub-scales of PMI ranged from 0.24 to 0.88 (Table 5). In addition, when these results were examined together with the correlation coefficients given in Table 4, it was observed that the values generally indicated a moderate and high level of relationship between the sub-scales. (Büyüköztürk, 2014).

Table 5. Correlation values between the sub-scales of PMI

\begin{tabular}{lccccccc}
\hline & Factor 1 & Factor 2 & Factor 3 & Factor 4 & Factor 5 & Factor 6 & Total \\
\hline Factor 1 & 1 & $0.57^{* *}$ & $0.67^{* *}$ & $0.56^{* *}$ & $0.4^{* *}$ & $0.75^{* *}$ & $0.88^{* *}$ \\
Factor 2 & $0.57^{* *}$ & 1 & $0.49^{* *}$ & $0.34^{* *}$ & $0.24^{* *}$ & $0.55^{* *}$ & $0.72^{* *}$ \\
Factor 3 & $0.67^{* *}$ & $0.49^{* *}$ & 1 & $0.66^{* *}$ & $0.47^{* *}$ & $0.73^{* *}$ & $0.85^{* *}$ \\
Factor 4 & $0.56^{* *}$ & $0.34^{* *}$ & $0.66^{* *}$ & 1 & $0.47^{* *}$ & $0.6^{* *}$ & $0.74^{* *}$ \\
Factor 5 & $0.4^{* *}$ & $0.24^{* *}$ & $0.47^{* *}$ & $0.47^{* *}$ & 1 & $0.45^{* *}$ & $0.56^{* *}$ \\
Factor 6 & $0.75^{* *}$ & $0.55^{* *}$ & $0.73^{* *}$ & $0.6^{* *}$ & $0.45^{* *}$ & 1 & $0.88^{* *}$ \\
Total & $0.88^{* *}$ & $0.72^{* *}$ & $0.85^{* *}$ & $0.74^{* *}$ & $0.56^{* *}$ & $0.88^{* *}$ & 1 \\
\hline
\end{tabular}

\subsection{Findings about Criterion Relation Validity}

For criterion validity PMI scores were analyzed according to the participants' gender and department. The results of t-test whether there was a significant difference between female and male students' PMI scores, are shown in Table 6. 
Table 6. $t$-test results for participants' PMI Scores according to the gender

\begin{tabular}{lccccc}
\hline PMI and factors & Groups & M & S & t & p \\
\hline Factor 1: Knowledge of cognition: & Female & 20.6 & 4.57 & 0.48 & 0.62 \\
declarative, procedural, conditional & Male & 20.3 & 4.39 & & \\
\hline Factor 2: Regulation of cognition: & Female & 12.76 & 3.74 & 1.26 & 0.2 \\
information management & Male & 12.25 & 3.67 & & \\
\hline Factor 3: Regulation of cognition: & Female & 14.89 & 3 & 0.83 & 0.4 \\
monitoring & Male & 14.63 & 2.73 & & \\
\hline Factor 4: Regulation of cognition: & Female & 11.67 & 2.45 & 1.01 & 0.31 \\
evaluation & Male & 11.4 & 2.38 & & \\
\hline Factor 5: Regulation of cognition: & Female & 8.19 & 1.6 & 2.32 & $0.02 *$ \\
debugging & Male & 7.77 & 1.79 & & \\
\hline Factor 6: Regulation of cognition: & Female & 18.21 & 3.53 & 0.4 & 0.68 \\
planning & Male & 18.36 & 3.36 & & \\
\hline \multirow{2}{*}{ Total PMI } & Female & 86.36 & 15.27 & 0.94 & 0.34 \\
& Male & 84.8 & 14.38 & & \\
\hline
\end{tabular}

According to Table 6 students' scores for physics metacognition didn't differ significantly factor $1\left(t_{(456)}=0.48, \mathrm{p}>.05\right)$, factor $2\left(\mathrm{t}_{(456)}=1.26, \mathrm{p}>.05\right)$, factor $3\left(\mathrm{t}_{(456)}=0.83, \mathrm{p}>.05\right)$, factor 4 $\left(\mathrm{t}_{(456)}=1.01, \mathrm{p}>.05\right)$, factor $6\left(\mathrm{t}_{(456)}=0.4, \mathrm{p}>.05\right)$ and total PMI $\left(\mathrm{t}_{(456)}=0.94, \mathrm{p}>.05\right)$. However students' scores for factor 5 differed in favor of the female students $\left(\mathrm{t}_{(456)}=2.32, \mathrm{p}<.05\right)$. For determining if there was a significant difference students' PMI scores and departments ANOVA test was used. Table 7 shows the results of ANOVA test for the participants' PMI scores according to the department.

Table 7. ANOVA results for participants' PMI scores according to department

\begin{tabular}{|c|c|c|c|c|c|c|}
\hline PMI and factors & Groups & $\mathbf{M}$ & $\mathbf{S}$ & $\mathbf{F}$ & $\mathbf{p}$ & Post-hoc \\
\hline \multirow{3}{*}{$\begin{array}{l}\text { Factor 1: Knowledge of } \\
\text { cognition: declarative, procedural, } \\
\text { conditional }\end{array}$} & Classroom t. & 19.96 & 5.13 & 2.73 & 0.06 & \multirow[t]{3}{*}{ - } \\
\hline & Science t. & 21 & 3.96 & & & \\
\hline & Engineering & 20 & 4.3 & & & \\
\hline \multirow{3}{*}{$\begin{array}{l}\text { Factor 2: Regulation of cognition: } \\
\text { information management }\end{array}$} & Classroom t. & 12.52 & 3.59 & 0.15 & 0.85 & \multirow{3}{*}{ - } \\
\hline & Science t. & 12.72 & 3.7 & & & \\
\hline & Engineering & 12.73 & 4.45 & & & \\
\hline \multirow{3}{*}{$\begin{array}{l}\text { Factor 3: Regulation of cognition: } \\
\text { monitoring }\end{array}$} & Classroom t. & 14.48 & 3.31 & 6.21 & $0.00^{*}$ & \multirow{3}{*}{$\begin{array}{l}S>C \\
S>E\end{array}$} \\
\hline & Science t. & 15.28 & 2.5 & & & \\
\hline & Engineering & 13.92 & 2.99 & & & \\
\hline \multirow{3}{*}{$\begin{array}{l}\text { Factor 4: Regulation of cognition: } \\
\text { evaluation }\end{array}$} & Classroom t. & 11.22 & 2.73 & 4.45 & $0.01^{*}$ & \multirow{3}{*}{$\mathrm{S}>\mathrm{C}$} \\
\hline & Science t. & 11.93 & 2.16 & & & \\
\hline & Engineering & 11.5 & 2.23 & & & \\
\hline \multirow{3}{*}{$\begin{array}{l}\text { Factor 5: Regulation of cognition: } \\
\text { debugging }\end{array}$} & Classroom t. & 8 & 1.74 & 6.03 & $0.00 *$ & \multirow{3}{*}{$\mathrm{S}>\mathrm{E}$} \\
\hline & Science t. & 8.29 & 1.45 & & & \\
\hline & Engineering & 7.38 & 2 & & & \\
\hline \multirow{3}{*}{$\begin{array}{l}\text { Factor 6: Regulation of cognition: } \\
\text { planning }\end{array}$} & Classroom t. & 17.68 & 3.88 & 4.75 & $0.00 *$ & \multirow{3}{*}{$\mathrm{S}>\mathrm{C}$} \\
\hline & Science t. & 18.73 & 3.15 & & & \\
\hline & Engineering & 18 & 3 & & & \\
\hline \multirow{3}{*}{ Total PMI } & Classroom t. & 83.89 & 17.4 & 4.14 & $0.01 *$ & \multirow{3}{*}{$\mathrm{S}>\mathrm{C}$} \\
\hline & Science t. & 87.98 & 12.8 & & & \\
\hline & Engineering & 84.3 & 14 & & & \\
\hline
\end{tabular}

According to Table 7 students' scores for physics metacognition didn't differ significantly regarding to the department in factor $1\left(F_{(2,455)}=2.73, \mathrm{p}>.05\right)$ and, factor $2\left(\mathrm{~F}_{(2,455)}=0.15\right.$, $\mathrm{p}>.05)$. There is a significant difference between students who attend science and classroom 
teaching program in factor $3\left(\mathrm{~F}_{(2,455)}=6.21, \mathrm{p}<.05\right)$, factor $4\left(\mathrm{~F}_{(2,455)}=4.45, \mathrm{p}<.05\right)$, factor 6 $\left(\mathrm{F}_{(2,455)}=4.75, \mathrm{p}<.05\right)$ and total PMI scores $\left(\mathrm{F}_{(2,455)}=4.14, \mathrm{p}<.05\right)$ in favor of science teaching students. Also there is a significant difference between students who attend science classroom teaching and engineering program in factor $3\left(\mathrm{~F}_{(2,455)}=6.21, \mathrm{p}<.05\right)$ and factor $5\left(\mathrm{~F}_{(2,455)}=6.03\right.$, $\mathrm{p}<.05)$ in favor of science teaching students.

\subsection{Findings Related to the Test-Retest Method}

To determine the reliability of the test-retest method, the PMI was administered to 52 students at 40 days interval, and Pearson product-moment correlation coefficients were calculated. These correlation coefficients were 0.78 for the entire scale, 0.76 for the factor $1,0.73$ for the factor $2,0.86$ for the factor $3,0.76$ for the factor $4,0.82$ for the factor 5 and, 0.85 for the factor 6 .

\section{DISCUSSION and CONCLUSION}

The use of standardized measurement instruments tested in international validity and reliability studies increases the quality of research. Furthermore, the adaptation of scales that are sufficiently known in international publications to Turkish allows researchers obtain comparable data in a shorter time and facilitates communication (Şahin, 1994). From this perspective, PMI developed by Taasoobshirazi and Farley (2013), consisting of 24 items and six sub-scales, was adapted to Turkish in the current study.

In order to minimize the differences between cultures in the adaptation process, language and field experts were consulted. CFA was applied to test the structure of the adapted scale. The values obtained from CFA were within the accepted ranges reported in the literature. In other words, the calculated fit indices indicated that the tested model was acceptable. In addition, the moderate- and high-level correlations found between the factors confirmed that divergent validity was achieved. The test-retest scores were calculated to further improve reliability. The t-test conducted between the mean item scores of the upper $27 \%$ and lower $27 \%$ groups for the discriminative power of the items revealed that the differences were significant for all items. Cronbach's alpha reliability coefficient for the whole scale was calculated as .93.

In conclusion, the factors of the adapted version of the PMI scale and the items under these factors had the same structure as the original PMI. The results obtained from the analyses showed that the adapted PMI had acceptable psychometric values (Klein, 1998). The item distribution was as follows: six items in Factor 1 (knowledge of cognition: declarative, procedural, conditional), four items in Factor 2 (regulation of cognition: information management), four items in Factor 3 (regulation of cognition: monitoring), three items in Factor 4 (regulation of cognition: evaluation), two items in Factor 5 (regulation of cognition: debugging), and five items in Factor 6 (regulation of cognition: planning).

In the Turkish literature, there is no measurement tool that evaluates the physics metacognition of high school and university students. Therefore, it is considered that the adapted PMI will greatly contribute to the field. However, the number of participants and experts was limited to those specified in the method section. In addition, validity of conformity with an equivalent scale was not undertaken. Therefore, the validity of the scale can be further investigated using different scales related to physics and science education. The Turkish PMI presented in the current study can be applied to evaluate the level of high school and university students' metacognition in solving physics problems. It can also be employed to determine the degree to which various methods and techniques affect physics metacognition. In future studies, the validity and reliability analyses of the adapted scale can be retested on data to be obtained from students enrolled in different departments of universities, as well as high school students to increase the generalizability of the adapted scale. 


\section{Acknowledge}

This study was supported by the Yozgat Bozok University Research Fund (Project Number: $6602 \mathrm{a}-\mathrm{EF} / 18-155)$. The abstract of this study was presented at $17^{\text {th }}$ Classroom Teaching Education Symposium (USOS 2018).

\section{ORCID}

Zeynep Koyunlu Ünlü (iD https://orcid.org/0000-0003-3627-1809

İlbilge Dökme (iD) https://orcid.org/0000-0003-0227-6193

\section{REFERENCES}

Abd-El-Khalick, F., \& Akerson, V. (2009). The influence of metacognitive training on preservice elementary teachers' conceptions of nature of science. International Journal of Science Education, 31, 2161-2184.

Akben, N. (2018). Effects of the problem-posing approach on students' problem solving skills and metacognitive awareness in science education. Research in Science Education, https://doi.org/10.1007/s11165-018-9726-7.

Anzai, Y., \& Yokoyama, T. (1984). Internal models in physics problem solving. Cognition and Instruction, 1(4), 397-450.

Blakey, E., \& Spence, S. (1990). Developing metacognition. Syracuse, NY: Clearinghouse on Information Resources (ERIC Document Reproduction Service No. ED 327 218). http://www.nagc.org/index.aspx?id=205 Date of access: 11.01 .2018

Brown, A. L. (1978). Knowing when, where, and how to remember: a problem of metacognition. In R. Glaser (Ed.), Advances in instructional psychology, 7, 55-111. New York: Academic Press.

Büyüköztürk, Ş. (2004). Sosyal bilimler için veri analizi el kitabı [Handbook of data analysis for social sciences]. Ankara: Pegem A Yayıncilık.

Chi, M.T.H. (2006). Two approaches to the study of experts' characteristics. In N. Charness, P.J. Feltovich, R.R. Hoffman, \& K.A. Ericsson (Eds.), The Cambridge handbook of expertise and expert performance (pp. 21-30). New York, NY: Cambridge University Press.

Colthorpe, K., Sharifirad, T., Ainscough, L., Anderson, S., \& Zimbardi, K. (2018). Prompting undergraduate students' metacognition of learning: implementing 'meta-learning' assessment tasks in the biomedical sciences. Assessment \& Evaluation in Higher Education, 43, 272-285.

Dianovsky, M. T., \& Wink, D. J. (2012). Student learning through journal writing in a general education chemistry course for pre-elementary education majors. Science Education, 96, 543-565.

Erkuş, A. (2012). Psikolojide ölçme ve ölçek geliştirme-I: temel kavramlar ve işlemler [Measurement and scale development in psychology-I: basic concepts and procedures]. Ankara: Pegem Akademi.

Flavell, J. H. (1979). Metacognition and cognitive monitoring: a new area of cognitive development inquiry. American Psychologist, 34(10), 906-911.

Georghiades, P. (2004). Making pupils' conceptions of electricity more durable by means of situated metacognition. Research report. International Journal of Science Education, 26, 85-99.

Ghanizadeh, A. (2018). The interplay between reflective thinking, critical thinking, self monitoring, and academic achievement in higher education. Higher Education, 74, 101114.

Güss, C. D., \& Wiley, B. (2007). Metacognition of problem-solving strategies. Journal of Cognition and Culture, 7, 1-25. 
Hutner, T. L., \& Markman, A. B. (2016). Department-level representations: a new approach to the study of science teacher cognition. Science Education, 100(1), 30-56.

Kurnaz, M. A., \& Yiğit, N. (2010). Physics attitude scale: development, validity and reliability. Necatibey Faculty of Education Electronic Journal of Science and Mathematics Education, 4(1), 29-49.

Lai, E. R. (2011). Metacognition: a literature eeview. Research Reports. http://www.datec.org.uk/CHAT/chatmeta1.htm. Date of access: 24.12.2017

Meydan, C. H., \& Şeşen, H. (2015). Yapısal eşitlik modellemesi AMOS uygulamaları [Structural equation modeling AMOS applications]. Ankara: Detay yayıncılık.

Neto, A., \& Valente, M. O. (1997). Problem solving in physics: towards a metacognitively developed approach. Paper presented at the Annual Meeting of the National Association for Research in Science Teaching Oak Brook.

Nuhoğlu, H., \& Yalçın, N. (2004). The development of attitude scale for laboratory and the assessment of preservice teachers' attitudes towards physiscs laboratory. Journal of Gazi University Faculty of Education Kırsehir, 5(2), 317-327.

Nunnally, J. C. (1978). Psychometric theory (2nd ed.). New York: McGraw-Hill.

Nunnally, J.C., \& Bernstein, I. H. (1994). The assessment of reliability. Psychometric Theory, 3, 248-292.

Özturk, N. (2017). Assessing metacognition: theory and practices. International Journal of Assessment Tools in Education, 4(2), 134-148.

Patton, M. Q. (2002). Qualitative research \& evaluation methods. 3rd edition. Sage Publications, Inc.

Pintrich, P. R. (2002). The role of metacognitive knowledge in learning, teaching, and assessing. Theory Into Practice, 4, 218-225.

Rozencwajg, P. (2003). Metacognitive factors in scientific problem-solving strategies. European Journal of Psychology of Education, 18(3), 281-294.

Schraw, G., Crippen K. J., \& Hartley, K. (2006). Promoting self-regulation in science education: metacognition as part of a broader perspective on learning. Research in Science Education, 36, 111-139.

Schraw, G., \& Dennison, R. S. (1994). Assessing metacognitive awareness. Contemporary Educational Psychology, 19(4), 460-475.

Schraw, G., \& Moshman, D. (1995). Metacognitive theories. Educational Psychology Review, 7(4), 351-371.

Selcuk, G. S., Calıskan, S., \& Erol, M. (2007). The effects of gender and grade levels on Turkish physics teacher candidates' problem solving strategies. Journal of Turkish Science Education, 4(1), 92-100.

Seçer, İ. (2015). Psikolojik test geliştirme ve uyarlama süreci SPSS ve LISREL uygulamaları [Psychological test development and adaptation process SPSS and LISREL applications]. Ankara: Anı yayınc1lık.

Şahin, N. (1994). Psikoloji araştırmalarında ölçek kullanımı [Using scale in psychology research]. Türk Psikoloji Dergisi, 9(33), 19-26.

Stewart, J., \& Rudolph, J. (2001). Considering the nature of scientific problems when designing science curriculum. Science Education, 85, 207-222.

Taasoobshirazi, G., \& Farley, J. (2013). Construct validation of the physics metacognition inventory. International Journal of Science Education, 35(3), 447-459.

Taasoobshirazi, G., Bailey, M., \& Farley, J. (2015). Physics metacognition inventory part II: confirmatory factor analysis and rasch analysis. International Journal of Science Education, 37(17), 2769-2786.

Tekbıyık, A., \& Akdeniz, A. R. (2010). Ortaöğretim öğrencilerine yönelik güncel fizik tutum ölçeği: geliştirilmesi, geçerlik ve güvenirliği [Physical attitude scale for secondary 
school students: development, validity and reliability]. The Journal of Turkish Science Education, 7(4), 134-144.

Tezbaşaran, A. (1996). Likert tipi ölçek geliştirme klavuzu [Likert type scale development guide]. Ankara: Psikologlar Derneği Yayınları.

Thomas, G. P. (2012). Metacognition in science education: past, present and future considerations. In B. J. Fraser, K. Tobin, \& C. J. McRobbie (Eds.), Second international handbook of science education (vol. 24, pp. 131-144). Dordrecht: Springer.

Veenman, M. V. J. (2011). Learning to self-monitor and self-regulate. In R. Mayer, \& P. Alexander (Eds.), Handbook of research on learning and instruction (pp. 197-218). New York: Routledge.

Veenman, M. V. J., \& Spaans, M. A. (2005). Relation between intellectual and metacognitive skills: age and task differences. Learning \& Individual Differences, 15(2), 159-176.

Zohara A., \& Barzilai, S. (2013). A review of research on metacognition in science education: current and future directions. Studies in Science Education, 49, 121-169. 
Appendix 1. The Turkish Version of PMI

\begin{tabular}{|c|c|c|c|c|c|}
\hline Maddeler & 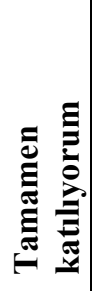 & 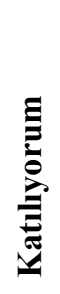 & 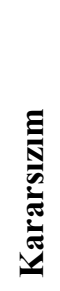 & 㤩 & 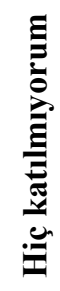 \\
\hline $\begin{array}{l}\text { 1. Bir fizik problemini çözmeye başlamadan önce problemin ne istediği } \\
\text { hakkında düşünürüm. }\end{array}$ & & & & & \\
\hline $\begin{array}{l}\text { 2. Bir fizik problemini çözerken hedeflerime ulaşıp ulaşmadığımı } \\
\text { belirli aralıklarla kendi kendime sorarım. }\end{array}$ & & & & & \\
\hline 3. Bir fizik problemini anlamadığımda yardım isterim. & & & & & \\
\hline $\begin{array}{l}\text { 4. Fizik problemlerini çözmemde yardımcı olması için serbest cisim } \\
\text { diyagramları çizerim. }\end{array}$ & & & & & \\
\hline $\begin{array}{l}\text { 5. Fizik problemlerini ne kadar iyi çözebildiğim konusunda sağlıklı bir } \\
\text { değerlendirme yaparım. }\end{array}$ & & & & & \\
\hline $\begin{array}{l}\text { 6. Fizik problemlerini çözerken, elimden gelenin en iyisini nasıl } \\
\text { yapacağımı bilirim. }\end{array}$ & & & & & \\
\hline $\begin{array}{l}\text { 7. Fizik problemlerini çözerken, kullandığım her bir stratejiye özgü } \\
\text { belirli bir amacım vardır. }\end{array}$ & & & & & \\
\hline $\begin{array}{l}\text { 8. Bir fizik problemini çözdükten sonra geriye dönüp çözümümü } \\
\text { kontrol ederim. }\end{array}$ & & & & & \\
\hline 9. Bir fizik problemini çözdükten sonra, cevabımı kontrol ederim. & & & & & \\
\hline $\begin{array}{l}\text { 10. Fizik problemlerini çözmede bana yardımcı olacak serbest cisim } \\
\text { diyagramları kullanırım. }\end{array}$ & & & & & \\
\hline $\begin{array}{l}\text { 11. Bir fizik problemini çözerken, problemi doğru çözmek için gereken } \\
\text { stratejiyi nasıl kullanacağımı bilirim. }\end{array}$ & & & & & \\
\hline $\begin{array}{l}\text { 12. Bir fizik problemini çözerken, belirli bir stratejiyi hangi sebeple } \\
\text { kullanacağımı bilirim. }\end{array}$ & & & & & \\
\hline $\begin{array}{l}\text { 13. Bir fizik problemini çözerken, belli bir stratejiyi ne zaman } \\
\text { kullanacağımı bilirim. }\end{array}$ & & & & & \\
\hline $\begin{array}{l}\text { 14. Bir fizik problemini çözmeden önce, sonucun ne çıkabileceğini } \\
\text { yaklaşık olarak tahmin ederim. }\end{array}$ & & & & & \\
\hline $\begin{array}{l}\text { 15. Bir fizik problemini çözerken, problemi ne kadar doğru çözüyor } \\
\text { olduğuma dair kendi kendime sorular sorarım. }\end{array}$ & & & & & \\
\hline $\begin{array}{l}\text { 16. Bir fizik problemini çözerken, problemi ne kadar doğru çözüyor } \\
\text { olduğumu belirli aralıklarla değerlendiririm. }\end{array}$ & & & & & \\
\hline $\begin{array}{l}\text { 17. Bir fizik problemini çözdükten sonra, doğru yöntemleri uygulayıp } \\
\text { uygulamadığımı görmek için çözümümü gözden geçiririm. }\end{array}$ & & & & & \\
\hline $\begin{array}{l}\text { 18. Fizik problemlerinin çözümü için serbest cisim diyagramlarının } \\
\text { neden önemli olduğunu bilirim. }\end{array}$ & & & & & \\
\hline $\begin{array}{l}\text { 19. Bir fizik problemini çözmeye başlamadan önce, problemi nasıl } \\
\text { çözeceğimi planlarım. }\end{array}$ & & & & & \\
\hline $\begin{array}{l}\text { 20. Bir fizik problemini çözmeden önce problemin önemli kısımlarının } \\
\text { tamamını tespit ederim. }\end{array}$ & & & & & \\
\hline $\begin{array}{l}\text { 21. Bir fizik problemini çözerken, hedeflerime ulaşıp ulaşmadığımı } \\
\text { kendi kendime sorarım. }\end{array}$ & & & & & \\
\hline $\begin{array}{l}\text { 22. Çözmeye çalıştığım fizik problemlerini anlamadığım zaman yardım } \\
\text { isterim. }\end{array}$ & & & & & \\
\hline 23. Bir fizik problemini çözerken serbest cisim diyagramları çizerim. & & & & & \\
\hline $\begin{array}{l}\text { 24. Bir fizik problemini çözmeden önce problemde gerek duymadığım } \\
\text { bilgileri elerim. }\end{array}$ & & & & & \\
\hline
\end{tabular}

